\title{
Early individual growth of Eucryphia cordifolia and Laurelia sempervirens planted under different competition conditions in south- central Chile
}

\author{
Daniel Uteau, and Pablo J. Donoso \\ Facultad de Ciencias Forestales, Universidad Austral de Chile. Casilla 567, Valdivia, Chile.
}

\begin{abstract}
D. Uteau, and P.J. Donoso. 2008. 2009. Early individual growth of Eucryphia cordifolia and Laurelia sempervirens planted under different competition conditions in south-central Chile. Cien. Inv. Agr. 36(1):85-96. Few studies have focused on forest research in plantations with Chilean native species midtolerant to shade. Such species may use resources that intolerant species cannot, increasing the total site productivity. This study aimed to define the factors that explain the growth of Eucryphia cordifolia Cav. and Laurelia sempervirens (Ruiz et Pavón) Tul., two midtolerant species of southern Chile. We sought to determine the effect on these species of competition in mixed-species plantations. At the time of this study, the plantations were 4 to 22 years old. Two competition indices were analyzed for each species: the Growing Space Polygon (GSP) and the Canopy Overlap (CO). The GSP proved to be very useful in predicting the growth in the older plantations where E. cordifolia and L. sempervirens had their crowns below the main canopy, suggesting strong competition for water and nutrients (also called symmetric competition). In contrast, in young plantations (around 10 years old), growth was better explained by $\mathrm{CO}$, suggesting that competition occurs mainly for light (also called asymmetric competition). Silvicultural techniques that could improve the growth of these species in mixed plantations were proposed, such as an earlier thinning entry to provide these species with more room for light, as dictated by their intermediate tolerance to shade.
\end{abstract}

Key words: Competition index, forest, growth, growing space polygon, crown competition, midtolerant species, silviculture.

\section{Introduction}

Forest plantations with native Chilean species have focused on species of the genus Nothofagus (Donoso et al. 1999a). These are pioneer species, which are characterized by intolerance to shade and fast growth; they are used to rapidly cover bare surfaces in their natural habitat. However, other species more tolerant to shade are important components of native forests in

Reveived 30 April 2008. Accepted 30 September 2008 Corresponding autor: danieliteau@uach.cl the Central South zone of Chile; in secondary forests dominated by species of Nothofagus, shade-tolerant species compose an inferior tree stratum under the dominant canopy. For example, in the Central South zone in Chile, it is common to find Laurelia sempervirens in secondary forests dominated by $N$. obliqua (Donoso et al. 1993; Lusk and Ortega 2003) and Eucryphia cordifolia in secondary forests dominated by $N$. dombeyi (Donoso et al., 1999b). These species have been proposed for a mixed silvicultural scheme, where several species and ages are employed (sensu Kelty 1992; Trenbath 1981; Vandermeer 1989). This sort of 
scheme involves a greater diversity of strata occupied by different species and provides more benefits than monocultivation, as resources may be used complementarily (Kelty 1992). In the forests dominated by Nothofagus spp., for example, it has been proven that the basal area of the species of the inferior canopy is additive to the basal area of the upper canopy, as in forests of second growth (adult forests) (Lusk and Ortega 2003; Donoso and Lusk 2007).

Among the semitolerant species of the native forest, E. cordifola, L. sempervirens, Persea lingue, and Gevuina avellana are considered to have high lumber value (Diaz-Vaz et al., 1989) and good growth rates (Vita 1977, González et al., 1997, Barría, 1996). These characteristics reflect that the development of silviculture forests mixed with native species represents a favorable alternative from the ecological, environmental and even the aesthetic points of view, as well as with regard to productivity. It is possible to achieve higher productivity in mixed forests with structures and species enabling a complementary use of resources, as compared to pure forests (Lusk and Ortega, 2003). This represents additive productivity, to be explored in secondary adult forests and plantations.

Currently, in the province of Valdivia, Chile, several plantations of E. cordifolia and L. sempervirens, two species semitolerant to shade (Escobar et al. 2006, Donoso et al. 2006), have been established, in different site conditions and forest types. The objective of this work was to describe the development of these species in different site conditions, considering the environmental and silvicultural variables. This work intends to explain growth as it is affected by the competition between $E$. cordifolia and $L$. sempervirens individuals in mixed plantations with native species in five areas of study located within the province of Valdivia, Chile.

\section{Materials and methods}

\section{Areas of study}

Five locations were selected (Arboretrum, The Palmas, Chucaypulli, Riñihue and Licán) within the Province of Valdivia in the Central South zone in Chile $\left(40-41^{\circ} \mathrm{S}\right.$ and $\left.73-75^{\circ} \mathrm{W}\right)$. Four corresponded to mixed plantations of native species including E. cordifolia or L. sempervirens, and one corresponded to a $L$. sempervirens plantation under the open canopy of an adult forest dominated by $N$. obliqua (Figure 1). This region is characterized by a temperaterainy climate with Mediterranean influence. The annual precipitations vary between 1.390 and $2.940 \mathrm{~mm}$. The mean annual temperature varies between 11.4 and $12.8^{\circ} \mathrm{C}$; in winter, the monthly mean temperatures range from 5.4-10 $.7^{\circ} \mathrm{C}$ and in summer from 13.7 to $19.0^{\circ} \mathrm{C}$. The number of days with frost varies between 36 and 77 per year (Huber 1970). The soils are acidic, $>40 \mathrm{~cm}$ deep, and derived from volcanic ash belonging to several soil series (Table 1; CIREN, 1999).

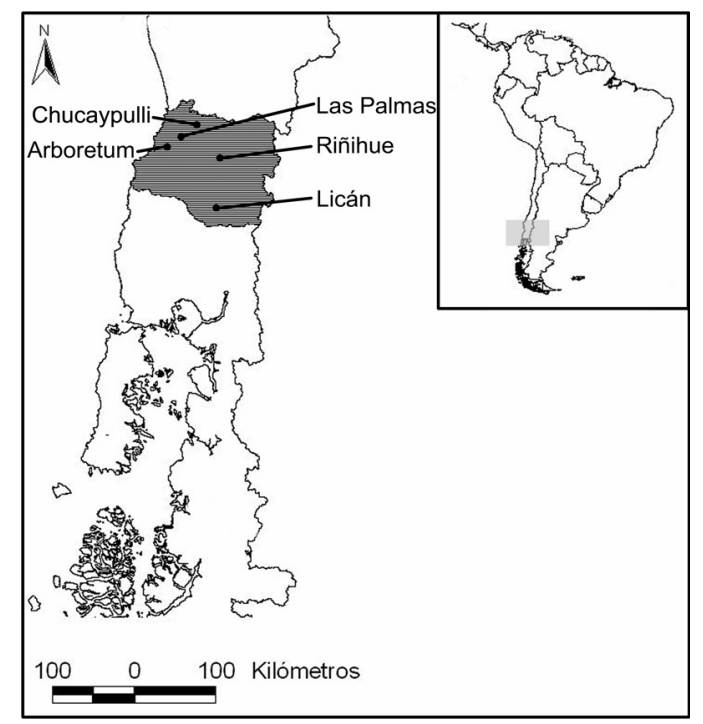

Figure 1. Geographical location of the study areas.

All the evaluated plantations were established at 2 x 2 m with bare-rooted 2-year-old plants maintained in a greenhouse, of the 1/1 type, with an intermediate transplant in order to achieve more distance among plants. In Arboretum, there is a 20-year-old plantation of L. sempervirens under a pruned canopy of an adult forest dominated by $N$. obliqua. In the Las Palmas farm, there is an open field plantation of 22-year-old $N$. nervosa, where specimens of E. cordifolia and $L$. 
Table 1. General information for the study areas.

\begin{tabular}{llll}
\hline Location & $\begin{array}{l}\text { Altitude } \\
\text { m a.s.l. }\end{array}$ & Soil series & Geographical location \\
\hline Arboretum & 50 & Asoc. Tres Cruces & Coastal mountain range \\
Las Palmas & 100 & Los Ulmos & Coastal mountain range \\
Chucaypulli & 100 & Pelchuquín & Pre-Coastal mountain range \\
Riñihue & 150 & Liquiñe & Pre-Andes mountain range \\
Licán & 700 & Liquiñe & Andes mountain range \\
\hline
\end{tabular}

sempervirens were planted 12 years ago. The Chucaypulli farm has a mixed coetaneous 11year-old plantation composed of $N$. obliqua, $N$. nervosa, N. dombeyi, Gevuina Avellana, L. sempervirens and E. cordifolia. The plantation is arranged in lines of $N$. dombeyi, lines of $N$. obliqua and $N$. nervosa and lines of $N$. nervosa, G. avellana, L. sempervirens and E. cordifolia. The upper canopy is occupied by $N$. dombeyi, $N$. obliqua and $N$. nervosa, and the intermediate and lower canopy by L. sempervirens, E. cordifolia and G. avellana. In the Riñihue farm, there is a coetaneous mixed plantation of $N$. obliqua, $N$. nervosa and E. cordifolia that was 22-yearsold when evaluated in the present study. The plantation had a pruned sector and another without interventions, with E. cordifolia in both sectors occupying a lower canopy under Nothofagus, although previous records place E. cordifolia in the codominant canopy (Barría 1996). Finally, in Licán, there is a mixed 4-yearold plantation of $E$. cordifolia and $N$. dombeyi in clearances made for protection; the remaining forest consists of adult individuals of about $30 \mathrm{~m}$ tall, mainly $N$. dombeyi and Weinmannia trichosperma.

\section{Competition measurement}

Two indices of competition were created for this study, one polygonally and the other of overlapping area. The polygonal competition index was based on the proposal by Brown (1965), who suggests using the area potentially available (APA), defined as an irregular polygon formed around a subject tree(s), whose sides are lines traced between competitor trees (c) and the subject tree (Figure 2).

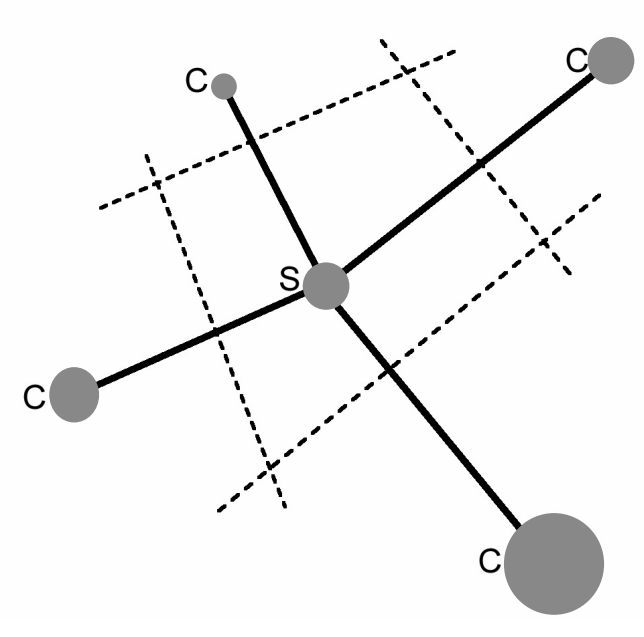

Figure 2. Growing Space Polygon (GSP), as modified by Moore et al. (1973). $\mathrm{S}=$ subject tree. $\mathrm{C}=$ competitor trees.

For this case, the mean point between the trees was proportional to the basal area, and it was calculated through the following relation (Moore et al., 1973):

$$
\mathrm{DP}_{\mathrm{sc}}=\frac{D_{s}^{2}}{\left(D_{s}^{2}+D_{c}^{2}\right)} \times \mathrm{D}_{\mathrm{sc}}
$$

where $\mathrm{DP}_{\mathrm{sc}}$ is the mean point between competitor and subject, $\mathrm{D}_{\mathrm{s}}$ is diameter to chest height (1.3 m; DAP) of the subject tree, $\mathrm{D}_{c}$ is DAP of the competitor tree, and $\mathrm{D}_{\text {sc }}$ is the distance between the subject tree and the competitor tree.

To estimate the index of overlapping area, the Stabler competition index was used (1951). This index may be applied easily in situations graphically described in Figure 3. 


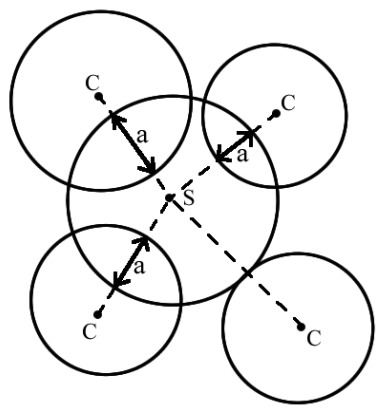

Figure 2. Graphic representation of the canopy radius overlap. $\mathrm{s}=$ subject tree, $\mathrm{c}=$ competitor, $\mathrm{a}=$ radial overlap width.

$$
I C S=\sum_{i=1}^{n} a_{a c}
$$

where ICS is the Stabler competition index, $\mathrm{a}_{\mathrm{sc}}$ is the roof of the canopy overlapping area between subject and competitor, and $\mathrm{n}$ is the number of competitors whose canopies overlap the subject.

The indices were calculated using 20 individuals of each species (E. cordifolia and L. sempervirens) per plantation, except in Arboretum, where 13 trees were randomly selected. DAP, total height, sociological position, distance to the closest competitors, diameter of the closest competitor specimens, azimuth and height of the competitor specimens were measured. Only those individuals of sociological position equal or superior to the subject tree, and the individuals at a distance $<10 \mathrm{~m}$ were considered as competitors. The sociological classification of canopies used corresponds to that defined by Synnott (1979) for mixed forests, according to the amount of light that the trees receive (Figure 4).

Development of indices for competition and statistical analysis

For the estimation of the corrected APA (Moore et al., 1973; Figure 3), the data of subject-competitor distance and azimuth were used to establish the locations of the individuals in an axis of Cartesian coordinates using an MS Excel ${ }^{\circledR}$ worksheet. Then, the coordinates were inserted in the graphic design worksheet of the Auto$\mathrm{CAD}^{\circledR}$ software (v. 2000, Autodesk Inc., San Rafael, California, EUA) to estimate the polygon area.

The Stabler competition index was obtained through direct calculations in an MS Excel ${ }^{\circledR}$ worksheet, when comparing the variables: distance subject-competitor, canopy radius of the competitor towards the subject (CS), and canopy radius of the subject towards the competitor (SC) through the following relation:

$$
C=\sum_{i=1}^{n}\left(C S_{i}+C S_{i}-\text { Dist }_{i}\right)
$$

where CC is the competition of canopies (m), $\mathrm{n}$ is the number of competitors whose canopies overlap with the subject, Dist is the distance between the subject and the competitor, CS is the canopy radius of the competitor towards the subject, and SC is the canopy radius of the subject towards the competitor.

Once APA and CC were obtained, possible relations with the mean annual increase in DAP (IMA) and in height (IMAAL) were established. The following models of regression were used:

Linear:

$$
\mathrm{y}=\mathrm{b}_{0}+\mathrm{b}_{1} \mathrm{x}
$$

Second order polynomial:

$$
y=b_{0}+b_{1} x+b_{2} x^{2}
$$

Third order polynomial:

$$
y=b_{0}+b_{1} x+b_{2} x^{2}+b_{3} x^{3}
$$

Logarithmic:

$$
\mathrm{y}=\mathrm{b}_{0}+\mathrm{b}_{2} \operatorname{Ln}(\mathrm{x})
$$

Exponential:

$$
\mathrm{y}=\mathrm{b}_{0} \mathrm{e}^{\mathrm{blx}}
$$




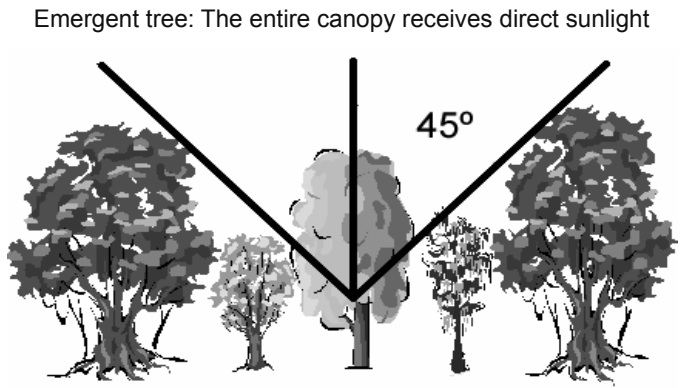

Higher canopy tree: The entire canopy receives direct sunlight
onto the top

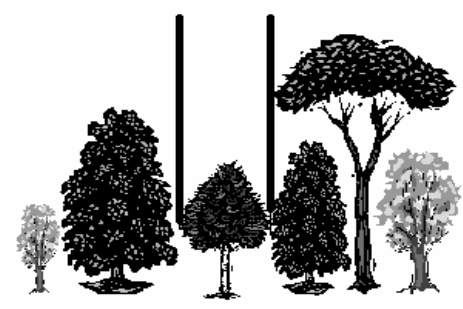

Lower canopy tree: Part of the canopy receives direct sunlight onto the top

Higher reserve tree: The canopy receives direct light only from one side
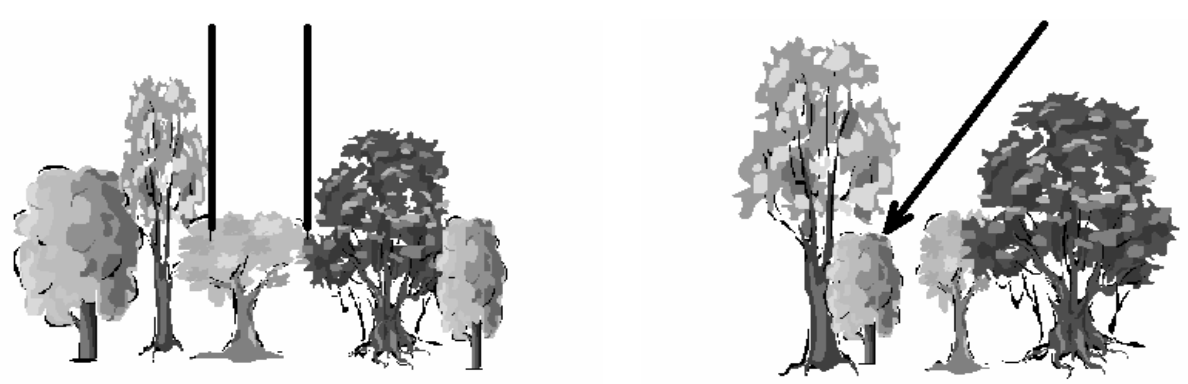

Lower reserve tree: Without direct sunlight

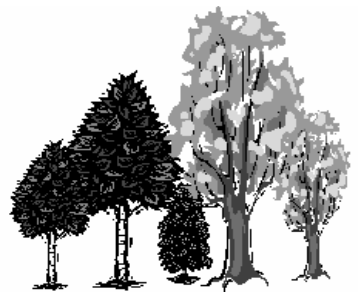

Figure 4. Canopy classification for mixed stands as proposed by Synnott (1979).

Potential:

$$
\mathrm{y}=\mathrm{b}_{0} \mathrm{x}^{\mathrm{b} 1}
$$

For selecting the best model, the recommendations by Cao et al. were followed (1980), favoring functions with higher coefficients of determination $\left(\mathrm{R}^{2}\right)$, then minor standard error, and finally, higher value of tabulated $F$. The dependent variables included in the final models were those with significance higher than $95 \%$. All the analyses were carried out with the statistical pack Systat ${ }^{\circledR}$ (v. 9.0, SPSS Inc., Chicago, Illinois, USA).

\section{Results}

The measurements were very homogeneous in the areas under study (Table 2), with the exception of E. cordifolia in Las Palmas. The highest increases were obtained for the E. cordifolia plantation in Licán.

The relations among the growth and competition variables are indicated in Table 3, considering the functions reaching a higher $\mathrm{R}^{2}$. Considering that in the Licán plantation canopies were still open, no relation was assigned between growth 
Table 2. Number of subject trees measured by species, and mean values of the variables recorded in each stand.

\begin{tabular}{|c|c|c|c|c|c|c|c|}
\hline \multirow[b]{3}{*}{ Variables $^{1}$} & \multicolumn{7}{|c|}{ Geographical locations } \\
\hline & Riñihue & Chucaypulli & Licán & Las Palmas & Chucaypulli & Arboretum & Las Palmas \\
\hline & \multicolumn{4}{|c|}{ Eucryphia cordifolia } & \multicolumn{3}{|c|}{ Laurelia sempervirens } \\
\hline Specimens, no. & 20 & 20 & 20 & 20 & 20 & 13 & 20 \\
\hline Age, years & 22 & 11 & 4 & 12 & 11 & 20 & 12 \\
\hline DAP, $\mathrm{cm}$ & 14.40 & 5.68 & 2.85 & 1.68 & 4.36 & 11.96 & 2.78 \\
\hline Height, $\mathrm{m}$ & 11.48 & 5.60 & 3.50 & 3.35 & 4.42 & 12.54 & 4.10 \\
\hline IMA, cm year ${ }^{-1}$ & 0.65 & 0.52 & 0.71 & 0.14 & 0.39 & 0.61 & 0.23 \\
\hline IMAAL m year $^{-1}$ & 0.52 & 0.51 & 0.88 & 0.28 & 0.40 & 0.63 & 0.34 \\
\hline $\mathrm{CC}, \mathrm{m}$ & 3.99 & 2.27 & 0.00 & 1.18 & 2.62 & 2.52 & 1.31 \\
\hline $\mathrm{APA}, \mathrm{m}^{2}$ & 5.29 & 3.66 & 3.00 & 0.13 & 5.39 & 2.45 & 0.026 \\
\hline IMA CV,\% & 21.80 & 23.10 & 38.40 & 36.50 & 42.70 & 30.50 & 75.80 \\
\hline IMAAL CV, $\%$ & 24.00 & 20.30 & 26.90 & 31.30 & 36.70 & 16.20 & 59.10 \\
\hline $\mathrm{CC} \mathrm{CV}, \%$ & 69.90 & 38.90 & 0.00 & 59.10 & 49.00 & 54.00 & 74.50 \\
\hline $\mathrm{APA} C \mathrm{CV}, \%$ & 50.50 & 60.90 & 81.90 & 121.90 & 59.30 & 174.60 & 131.00 \\
\hline
\end{tabular}

${ }^{1} \mathrm{DAP}=$ Diameter at $1.3 \mathrm{~m}(\mathrm{~cm}) ; \mathrm{IMA}=$ Mean annual increment in diameter $(\mathrm{cm}) ; \mathrm{IMAAL}=$ Mean annual increment in height $(\mathrm{m})$; $\mathrm{CC}=\mathrm{Crown}$ competition $(\mathrm{m})$; $\mathrm{APA}=$ Growing space polygon $\left(\mathrm{m}^{2}\right) ; \mathrm{RC}=$ Mean crown radius $(\mathrm{m}) ; \mathrm{CV} \%=$ Coefficient of variation (percent).

and competition variables.

The highest relations in IMA and IMAAL were obtained for Arboretum (L. sempervirens) and
Riñihue (E. cordifolia) stands, which were the oldest plantations (20 and 22 years, respectively). In these two cases, the increase was related

Table 3. Relation between growth and competition variables, including the regression model with best fit.

\begin{tabular}{|c|c|c|c|c|}
\hline Location & Equation $^{1}$ & $\mathrm{R}^{2}$ & $\mathrm{p}$ & $\mathrm{F}$ \\
\hline \multicolumn{5}{|c|}{ Laurelia sempervirens } \\
\hline \multirow{2}{*}{ Arboretum } & $\mathrm{IMA}=-0.0057 \mathrm{APA}^{2}+0.1157 \mathrm{APA}+0.4458$ & 0.97 & 0.0001 & 180.44 \\
\hline & $\mathrm{IMAAL}=0.6283 \mathrm{APA}^{0.0823}$ & 0.80 & 0.0020 & 12.07 \\
\hline \multirow{2}{*}{ Chucaypulli } & $\mathrm{IMA}=0.0303 \mathrm{CC}^{2}-0.097 \mathrm{CC}+0.4607$ & 0.47 & 0.0087 & 6.65 \\
\hline & $\mathrm{IMAAL}=0.0162 \mathrm{CC}^{3}-0.1299 \mathrm{CC}^{2}+0.3177 \mathrm{CC}+0.2388$ & 0.49 & 0.0210 & 4.50 \\
\hline \multirow{2}{*}{ Las Palmas } & $\mathrm{IMA}=0.1229 \mathrm{e}^{0.3068 \mathrm{CC}}$ & 0.19 & 0.0500 & 4.34 \\
\hline & IMAAL $=0.0834 C^{3}-0.4092 C^{2}+0.5564 C C+0.1294$ & 0.19 & 0.0500 & 4.30 \\
\hline \multicolumn{5}{|c|}{ Eucryphia cordifolia } \\
\hline \multirow{2}{*}{ Riñihue } & $\mathrm{IMA}=-0.0037 \mathrm{APA}^{2}+0.0814 \mathrm{APA}+0.3525$ & 0.73 & 0.0001 & 23.40 \\
\hline & $\mathrm{IMAAL}=-0.0027 \mathrm{APA}^{2}+0.0615 \mathrm{APA}+0.2895$ & 0.49 & 0.0030 & 8.22 \\
\hline \multirow[b]{2}{*}{ Las Palmas } & $y=4914,6 x^{3}-385,91 x^{2}+8,6457 x+0,1098$ & 0.79 & 0.0001 & 43.96 \\
\hline & IMAAL $=0.6055 \mathrm{APA}^{0.1576}$ & 0.56 & 0.0001 & 23.21 \\
\hline
\end{tabular}

${ }^{1} \mathrm{IMA}=$ Mean annual increment in diameter $(\mathrm{cm}) ; \mathrm{IMAAL}=$ Mean annual increment in height $(\mathrm{m}) ; \mathrm{CC}=$ Crown competition $(\mathrm{m})$; APA= Growing space polygon $\left(\mathrm{m}^{2}\right) ; \mathrm{N}=20$ except Arboretum $(\mathrm{N}=13)$

directly to the APA, with CC exerting only weak influence. The greatest influence of CC was observed in the youngest plantations. 


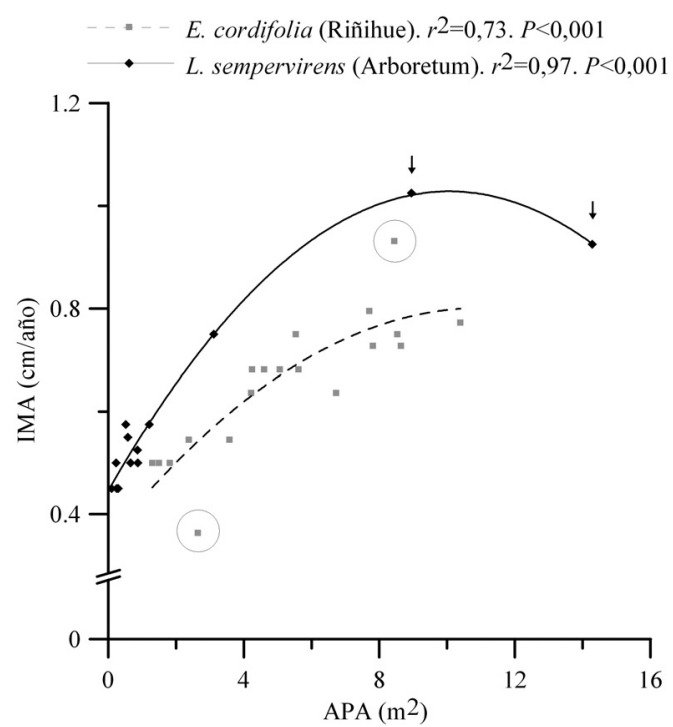

Figure 5. Relation between diameter at breast height growth (IMA) and growing space polygon (APA) for $E u$ cryphia cordifolia (Riñihue) and for Laurelia sempervirens (Arboretum).

There was a high relation between IMA and APA for E. cordifolia in the Riñihue farm (Figure 5). When the two outliers were eliminated (test made in Systat $^{\circledR}$ ), the $\mathrm{R}^{2}$ increased from 0.73 to 0.86 . In other words, the model's capacity to explain the growth variance was improved in $13 \%$ of calculations. As for $L$. sempervirens in Arboretum, the IMA increased up to an APA of $\sim 8 \mathrm{~m}^{2}$, but then decreased (Figure 5). E. cordifolia in Las Palmas also presented a good IMA-APA relation. The curve presents an ascending relation where slight increases of APA (values up to $0.2 \mathrm{~m}^{2}$ ) involve a strong relative increase in IMA (Figure 6).

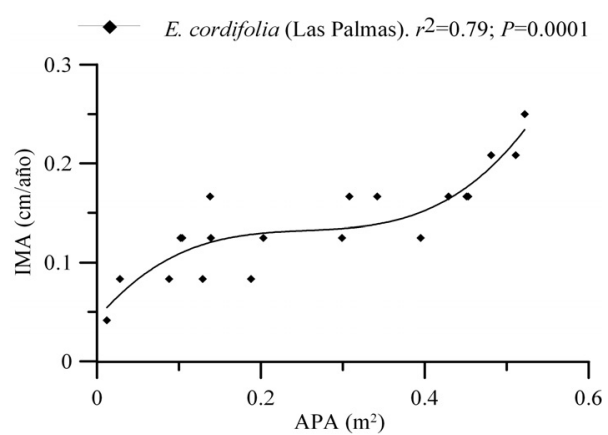

Figure 6. Relation between diameter at breast height growth (IMA) and growing space polygon (APA) for $E u$ cryphia cordifolia (Las Palmas).
The relations between the growths in height and diameter with $\mathrm{CC}$ were evident in curves with clouds of dispersed points showing a low correlation among the variables, with a $\mathrm{CC}$ point higher than 1.7 (Figure 7).

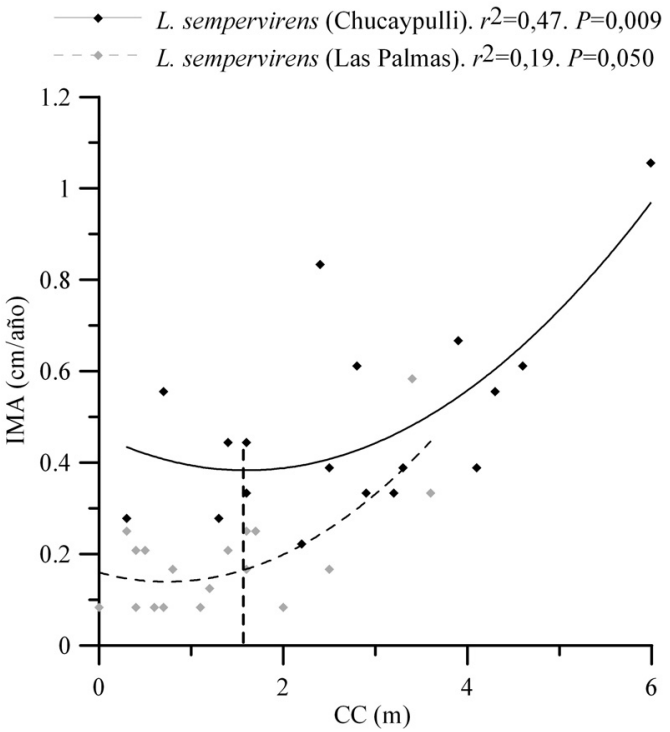

Figure 7. Relation between diameter at breast height growth (IMA) and canopy overlap (CC) for Laurelia sempervirens (Chucaypulli) and for Laurelia sempervirens (Las Palmas).

A more detailed analysis of the relation between canopy radius $(\mathrm{CR})$ and the $\mathrm{CC}$ provides a possible explanation. Figure 8 shows the lack of a relation for L. sempervirens in Chucaypulli until the point where the $\mathrm{CC}$ reaches a value of 1.4 $\mathrm{m}$; this point represents the onset of a positive relation between both variables.

In Figure 8, it may be observed that the competition of canopies is related to individual growth, provided that there is a positive relation between canopy radius and canopy competition. This point may be noted in both cases $(\mathrm{CC}>$ $1.5)$ where the relation starts to improve. 


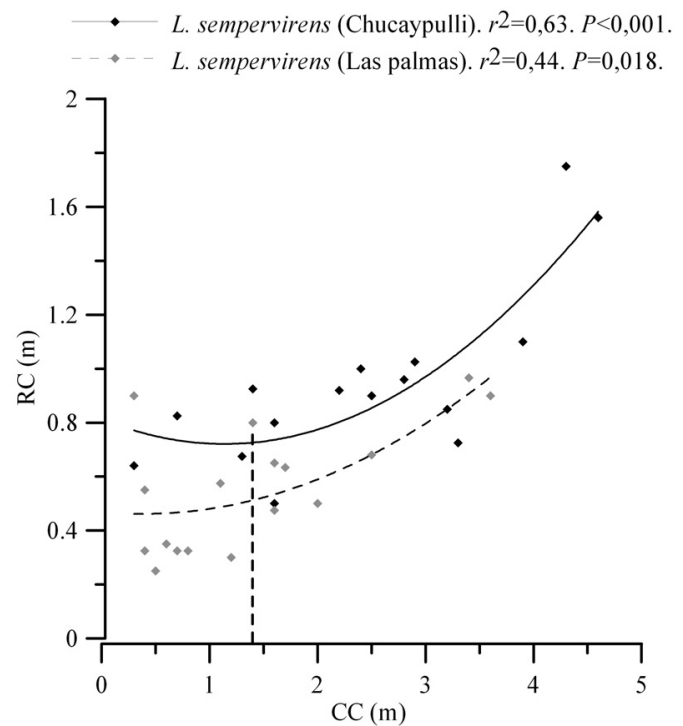

Figure 8. Relation between canopy radius and canopy overlap for Laurelia sempervirens (Chucaypulli and Las Palmas).

\section{Discussion}

In plantations under the canopy, the potentially available area is an important factor to explain growth in the diameter and height of E. cordifolia and $L$ sempervirens, particularly in older plantations. Therefore, growth is highly influenced by the relative DAP of the competitor species, which may occur when individuals, without direct light, begin to compete strongly for nutrients and water. In this regard, caution is necessary when incorporating species that are semitolerant to shade in plantations with species that are intolerant to shade and exhibit fast growth (e.g., N. obliqua, N. dombeyi and N. nervosa). In cases of plantations that have been planned coetaneously, we observed improved behavior of the species of interest. However, the fast growth of Nothofagus species has overwhelmed E. cordifolia and L. sempervirens, which were at the limit of maximum tolerable stress (particularly after 10 years of age). This may be observed in the E. cordifolia plantation in Riñihue, where there were individuals exhibiting robust growth in a thinning sector and other individuals displaying weak growth in sectors that had not been thinned (Barría, 1996; Martínez, 2004).
Canopy competition was not linked to individual growth, but it was significant in young plantations (i.e., $<10$ years old). This relation, although less evident than that of growth with APA, may be due to the fact that available root space was not a limiting factor (at least in soils where the plantations were located) during the first year of growth. Therefore, the competition during the first years was mainly for light. This was observed in the E. cordifolia plantation in Licán, where APA was not related to growth, but where the individuals compete strongly in space while expanding their canopies. The variable beginning of the canopy becomes a predictor starting at approximately $1.5 \mathrm{~m}$ of overlap. On the basis of the relation of canopy radius $v s$. canopy competition, $1.5 \mathrm{~m}$ of overlap occurred when the canopy radius reached between 0.6 and $0.8 \mathrm{~m}$, which implies a canopy diameter of 1.2 to $1.6 \mathrm{~m}$. In the traditional plantation scheme $(2 \times 2$ or $2 \times 3 \mathrm{~m})$, the canopy closure was associated with these canopy diameters; canopy competition was significantly associated with individual growth.

E. cordifolia and L sempervirens were semitolerant species, growing considerably better in semi-shaded conditions than under completely shaded conditions under the canopy. Based on these results, two silvicultural strategies can be recommended to favor the growth of these species in mixed plantations: a) joint cultivation of these species along with dominant species at higher spaces than customary, b) thinning at early stages in order to avoid diminishing growth. The first strategy may have negative consequences on tree shape. However, this alternative has already been suggested for semitolerant species, in order to provide direct light on a portion of the canopy (Kelty, 1992). The second strategy consists in early thinning (probably pre-commercial) when plants are between 10 to 15 years old, in order to maintain good growth rates. In this regard, Barría (1996) detected initial rapid growth for E. cordifolia in the Riñihue plantation, similar to the growth observed at the Licán plantation, which allows E. cordifolia to remain in a codominant position in the plantation. This situation is reversed at the sixth year, when $N$. alpina and $N$. obliqua exceed $E$. cordifolia in height and diameter. 
This information suggests that thinning should be done early.

There was great variability in the results obtained. The highest increases in diameter were obtained for E. cordifolia $\left(0.71 \mathrm{~cm} \cdot\right.$ year $\left.^{-1}\right)$ and $L$. sempervirens $\left(0.61 \mathrm{~cm} \cdot\right.$ year $\left.^{-1}\right)$ in Licán and Arboretum, respectively. These values, although lower than the values previously reported (Donoso, 1993), represent a promising range of growth for these species, due to good environmental conditions and the use of high-quality plants. With regard to the increases in height, most of the plantations exhibited robust growth. The growths in height reported in this work for E. cordifolia were lower than the growth reported in Frutillar (Vita, 1977). However, in general, the growths in diameter were higher than the growths reported in other studies (Table 4). For L. sempervirens, the growths in height were lower overall than the reported growths in other studies (Table 4).

Table 4. D.B.H. and height growth for Eucryphia cordifolia and Laurelia sempervirens in this study and other studies.

\begin{tabular}{|c|c|c|}
\hline Study area & $\begin{array}{l}\text { IMA }^{1} \\
\mathrm{~cm} \cdot \text { year }^{-1}\end{array}$ & $\begin{array}{l}\text { IMAAL }^{1} \\
\text { m } \cdot \text { year }^{-1}\end{array}$ \\
\hline \multicolumn{3}{|c|}{ Laurelia. sempervirens: } \\
\hline Chucaypulli & 0.50 & 0.49 \\
\hline Arboretum & 0.61 & 0.63 \\
\hline Las Palmas & 0.23 & 0.34 \\
\hline Frutillar $1^{2}$ & 0.80 & 0.40 \\
\hline Frutillar $2^{2}$ & 0.90 & 0.50 \\
\hline San Martín ${ }^{3}$ & $\mathrm{~s} / \mathrm{i}$ & 0.21 \\
\hline \multicolumn{3}{|c|}{ Eucryphia cordifolia: } \\
\hline Riñihue & 0.65 & 0.52 \\
\hline Chucaypulli & 0.60 & 0.62 \\
\hline Licán & 0.71 & 0.88 \\
\hline Las Palmas & 0.14 & 0.28 \\
\hline Frutillar $^{2}$ & 1.00 & 0.50 \\
\hline San Martín ${ }^{3}$ & $\mathrm{~s} / \mathrm{i}$ & 0.40 \\
\hline
\end{tabular}

With the growth rates outlined and the good survival rates, it is feasible to propose silvicultural schemes comprising mixed species. In this type of plantation, the ideal design requires that species that are semitolerant of shade occupy a codominant canopy, which is not suppressed under species that are intolerant to shade and exhibit rapid growth, such as those of the genus Nothofagus spp. (sensu Kelty, 1992). In order to maintain this vertical structure over time, thinning is required to allow the semitolerant species to maintain their canopies in a codominant position. In this design, species such as E. cordifolia and L. sempervirens occupy the medium and inferior canopies of the dominant species. This portion of the canopy is inefficient for intolerant species, but efficient for semitolerant species (sensu Kelty 1992). A scheme of this type also presents challenges to the harvest cut; one alternative is a cut of varying protection (sensu Nyland, 2002). The residual trees of the harvest cut (strong and fewer in number than those remaining after habitual cuts) are left standing for a longer period than usual between this cut and the final cut; they are cut only when the semitolerant species have reached their harvest diameter. 


\section{Resumen}

D. Uteau y P.J. Donoso. 2008. 2009. Desarrollo individual temprano de Eucryphia cordifolia y Laurelia sempervirens plantadas en distintas condiciones de competencia en el centro-sur de Chile. Cien. Inv. Agr. 36(1):85-96. La investigación forestal en Chile en plantaciones con especies nativas semitolerantes a la sombra ha sido marginal. Estas especies pueden aprovechar los recursos disponibles para estratos intermedios del bosque aumentando la productividad bruta del sitio. Este estudio tuvo por objetivo describir el crecimiento de Eucryphia cordifolia y Laurelia sempervirens, dos especies semitolerantes del bosque Valdiviano de Chile, en función de su competencia arbórea en varias plantaciones mixtas y en un bosque adulto. La plantaciones evaluadas tuvieron entre 4 y 22 años al momento de realizar este trabajo. Para cada especie y en cada lugar de estudio, se calcularon dos índices de competencia de árboles individuales: competencia de copas (CC) y área potencialmente aprovechable (APA). En plantaciones de mayor edad, en las que los individuos de E. cordifolia y L. sempervirens se encontraron bajo el dosel arbóreo dominante, se notó una fuerte relación entre el APA y el crecimiento, lo cual sugiere una fuerte competencia por agua y nutrientes, es decir competencia simétrica. Por el contrario, en los individuos más jóvenes (alrededor de 10 años deedad), el crecimiento se vio mejor explicado por la competencia de copas, reflejando competencia principalmente por luz, es decir competencia asimétrica. Se proponen algunas estrategias silviculturales, entre ellas, adelantar un primer raleo de modo de proporcionar a estas especies más espacio para captación de luz, considerando su condición de especies semitolerantes a la sombra.

Palabras clave: Area potencialmente aprovechable, bosque, competencia de copas, crecimiento, especies semitolerantes, índices de competencia, silvicultura.

\section{References}

Barría, L.P. 1996. Comparación de la estructura y crecimiento de una plantación de Roble-Raulí, con una de Roble-Raulí-Ulmo en la Provincia de Valdivia. Tesis Ingeniero Forestal. Valdivia, Facultad de Ciencias Forestales, Universidad Austral de Chile, Valdivia, Chile. $110 \_$p.

Brown, G.S. 1965. Point density in stems per acre. New Zealand Journal of Forestry Research. Note $N^{\circ} 38.13 p$.

Cao, Q., H. Burckhart, and M. Timoty. 1980. Evaluation of two methods for cubic-volume prediction of loblolly pine to any merchanteable limit. Forest Science 26:71-80.

CIREN. 1999. Descripciones de Suelos Materiales y Símbolos. Estudio Agrológico de la Provincia de Valdivia - X Región. Publicación CIREN, Santiago, Chile. 196 p.

Diaz-Vaz, J.E., H. Poblete, R. Juacida, and F. Devlieger. 1989. Maderas Comerciales de Chile. Marisa Cúneo Ediciones, Valdivia, Chile. 91 p.

Donoso, C. 1993. Bosques Templados de Chile y Argentina; Variación, Estructura y Dinámica.
Cuarta ed. Editorial Universitaria. Santiago, Chile. 484 p.

Donoso, P.J., and C. Lusk. 2007. Differential effects of emergent Nothofagus dombeyi on growth and basal area of canopy species in an old-growth temperate rainforest. Journal of Vegetation Science 18:675-684.

Donoso, P.J., C. Donoso, and V. Sandoval. 1993. Proposición de zonas de crecimiento para renovales de roble y raulí en sus rangos de distribución natural. Bosque 14:37-56.

Donoso, C., D. Alarcón, and B. Escobar. 2006. Laurelia sempervirens. Páginas 314-324. En: C. Donoso (ed.). Las Especies Arbóreas de los Bosques Templados de Chile y Argentina : Autoecología. Marisa Cúneo Ediciones. Valdivia, Chile

Donoso, P.J., C. Cabezas, A. Lavanderos, and C. Donoso. 1999. Desarrollo de renovales de coihue común (Nothofagus dombeyi (Mirb.) Oerst.) en la cordillera de la costa y de los Andes de la provincia de Valdivia en sus primeros 25 años. Bosque 20:9-23

Donoso, P.J., M. González, B. Escobar, I. Basso, and L. Otero. 1999. Las plantaciones de Nothofagus alpina, N. obliqua y N. dombeyi en Chile. Pági- 
nas 177-244. En: C. Donoso y A. Lara (eds.). Silvicultura de los Bosques Nativos de Chile. Editorial Universitaria, Santiago, Chile.

Escobar, B., C. Donoso, and A. Zúñiga. 2006. Eucryphia cordifolia. Páginas 246-255. En: C. Donoso (ed.). Las Especies Arbóreas de los Bosques Templados de Chile y Argentina : Autoecología. Marisa Cúneo Ediciones. Valdivia, Chile

González, M.E., C. Donoso, and S. Fraver. 1997. Respuesta inicial de Eucryphia cordifolia, Laurelia sempervirens y Aextoxicon punctatum en plantaciones mixtas en sectores recientemente florecidos con Chusquea quila en el centro-sur de Chile. Bosque 18:53-60.

Huber, A. 1970. Diez años de observaciones climatológicas en la estación Teja-Valdivia (Chile) 1960-1969. Universidad Austral de Chile. Valdivia, Chile. 60 p.

Kelty, M.J. 1992. Comparative productivity of monocultures and mixed species stands. Pages 125141. In: M.J. Kelty, B.C. Larson and C.D. Oliver (eds.). The Ecology and Silviculture of Mixed Species Forests. Netherlands. Kluwer Academic Publishers. Norwell, Massachussetts, USA. 287 p.

Lusk, C., and A. Ortega. 2003. Vertical structure and basal area development in second-growth Nothofagus stands in Chile. Journal of Applied Ecology 40:639-645.

Martínez, A. 2004. Comparación del crecimiento de una plantación de Raulí, con una de Roble-Raulí y una de Roble-Raulí-Ulmo, en la precordillera
Andina de la Provincia de Valdivia. Tesis Ingeniero Forestal. Facultad de Ciencias Forestales, Universidad Austral de Chile. Valdivia, Chile. $31 \mathrm{p}$.

Moore, J.A., C.A. Budelsky, and R.C. Schlesinger. 1973. A new index representing individual tree competitive status. Canadian Journal of Forestry Research 3:495-500.

Nyland, R.D. 2002. Silviculture. Concepts and Applications. Second ed., Waveland Press, Inc., Long Grove, Illinois, USA. 682 p.

Stabler, G.R. 1951. Growth and spacing in an evenaged stand of Douglas-fir. Masters thesis, University of Michigan.

Synnott, T.J. 1979. A Manual of Permanent Plot Procedures for Tropical Rain Forests. Tropical Forestry Papers $\mathrm{N}^{\circ}$ 14. CFI, UK. $67 \mathrm{p}$.

Trenbath, B.R. 1981. Light use efficiency of crops and the potential for improvement through intercropping. Pages 141-154. In: R.W. Willey (ed.). Proceedings of the International Workshop on Intercropping. ICRISTAT, Hyderabad, India.

Vandermeer, J. 1989. The Ecology of Intercropping. Cambridge University Press, Cambridge, UK. $237 \mathrm{p}$.

Vita, A. 1977. Crecimiento de algunas especies forestales en el Arboretum del Centro Experimental Frutillar. X Región. Boletín Técnico 47. Facultad de Ciencias Forestales, Universidad de Chile. Santiago. Chile. 16 p. 
